\title{
DETERMINATION OF THE URGENCY OF UNDERTAKING LAND CONSOLIDATION WORKS IN THE VILLAGES OF THE SŁAWNO MUNICIPALITY
}

\author{
Przemysław Leń ${ }^{1}$, Monika Mika² \\ 1 Department of Environmental Engineering and Geodesy, University of Life Sciences in Lublin, Leszczyńskiego \\ 7 St., 20-069 Lublin, Poland, e-mail: przemyslaw.len@up.lublin.pl \\ 2 Faculty of Environmental Engineering and Land Surveying, Department of Land Surveying, University of \\ Agriculture in Krakow, Milocinska 40, 35-232 Rzeszow, Poland
}

Received: 2016.06.30

Accepted: 2016.08.20

Published: 2016.09.30

\begin{abstract}
The object of the paper is to analyze the spatial structure of land and identification of the needs of consolidation works and exchange of land in the villages of the Sławno municipality, lying in the district of Opoczno, in the Łódzkie Voivodship. The authors use the method of zero unitarisation for the purposes of determining the order of undertaking consolidation works and exchange of land in the area of research. The basis for calculation is the database of 19 factors $\left(\mathrm{x}_{1}-\mathrm{x}_{19}\right)$ characteristic for the listed five groups of issues, describing each of the following villages. The obtained results, in a form of synthetic meter for each village, allowed creating the hierarchy of the urgency of carrying out consolidation works. The problem of excessive fragmentation of farms, constituting the collections of a certain number of parcels, in a broader sense, is one of the elements that prevent the acceleration of reforms by conversion of the Land and Buildings Register (EGiB) in a full valuable real estate cadastre in Poland. The importance of the problem is highlighted by the fact that there are ecological grounds in the study area, significant from the point of view of environmental protection.
\end{abstract}

Keywords: land consolidation, statistical analyses, spatial structure of rural areas, Cadastre, environmental protection

\section{INTRODUCTION}

Modern image of the spatial structure of villages in central Poland was shaped by many factors. They include highly fragmented areas of the farms. The increase in the number of partitions of land, over the centuries, in the villages of the Opoczno district caused a large defect of the spatial structure at these areas. The statement of Noga [2001], correctly shows the condition of the spatial structure of the investigated area. This statement relates to the issue of overpopulation of the villages and the absence of migration opportunities as a factor causing that relatively large - 20-40 acre farms underwent continuous family partitions (all children inherited land). For this reason, the average acreage of farms has been continuously decreasing. Subsequent divi- sions of ownership led to a large fragmentation, but most of all, to the development of the ribbon patchwork of fields, characterizing the test area [Leń, Wójcik 2015].

The aim of the study is to determine the needs of consolidation and exchange of land in the villages of the Sławno municipality, lying in the district of Opoczno, in the Łódzkie Voivodship. To determine the order of undertaking consolidation and land exchange works the method of zero unitarisation was used. The basis for calculation was the base of five factors generating the investigated problem on the basis of which 19 factors characterizing each location were described and calculated. The obtained results in a form of synthetic meter for each village, allowed creating the hierarchy of the urgency of carrying out consolidation works. 


\section{CHARACTERISTICS OF THE ACCEPTED FACTORS}

To develop the ranking of the urgency of the needs of land consolidation works in the Sławno municipality, due to the spatial structure of land, 19 factors characterizing each village were defined and calculated, as illustrated by the data presented in Table 1.

The factors listed in Table 1 represent five groups of issues. The first two groups concerning the possession and use of land are represented by 10 factors. These are respectively factors $\left(\mathrm{x}_{1}, \mathrm{x}_{2}\right.$, $\left.\mathrm{x}_{3}, \mathrm{x}_{4}\right)$ for the first one and factors $\left(\mathrm{x}_{5}, \mathrm{x}_{6} \mathrm{x}_{7}, \mathrm{x}_{8} \mathrm{x}_{9}\right.$, $\mathrm{x}_{10}$ ) for the second mentioned group. They were calculated as a percentage of their share in the total area of the village, using data from a list of land acquired from EGiB [Leń, Głowienka 2015].

The third group are the factors describing the demographic conditions in the villages of the studied municipality $\mathrm{x}_{11}$ - number of inhabitants and $\mathrm{x}_{12}$ - number of inhabitants per square kilometer Information on the number of inhabitants was obtained from the Sławno municipal office.

In the fourth group of factors describing land fragmentation 5 indicators were assumed. Three of them: $x_{13}$ (overall area of the village), $\mathrm{x}_{14}$ (the total number of plots in the village) oraz $\mathrm{x}_{15}$ (number of plots in the individual sector) also used the data from EGIB. For the elaboration the average area of parcels in the individual sector $\left(\mathrm{x}_{16}\right)$ was also taken as a factor. For the refinement of the problem of fragmentation the index of fragmentation $\left(\mathrm{x}_{16}\right)$ was calculated on the basis of Leń, Noga 2010].
The last group of factors was related to the percentage of plots with no road access $\left(\mathrm{x}_{18}\right)$ and the percentage of the area of plots with no road access $\left(\mathrm{x}_{19}\right)$. For the purposes of this part of the study, GIS (Geographic Information System) tools were used, allowing a transparent and fast graphical presentation of research results. [Głowienka, Leń, 2016].

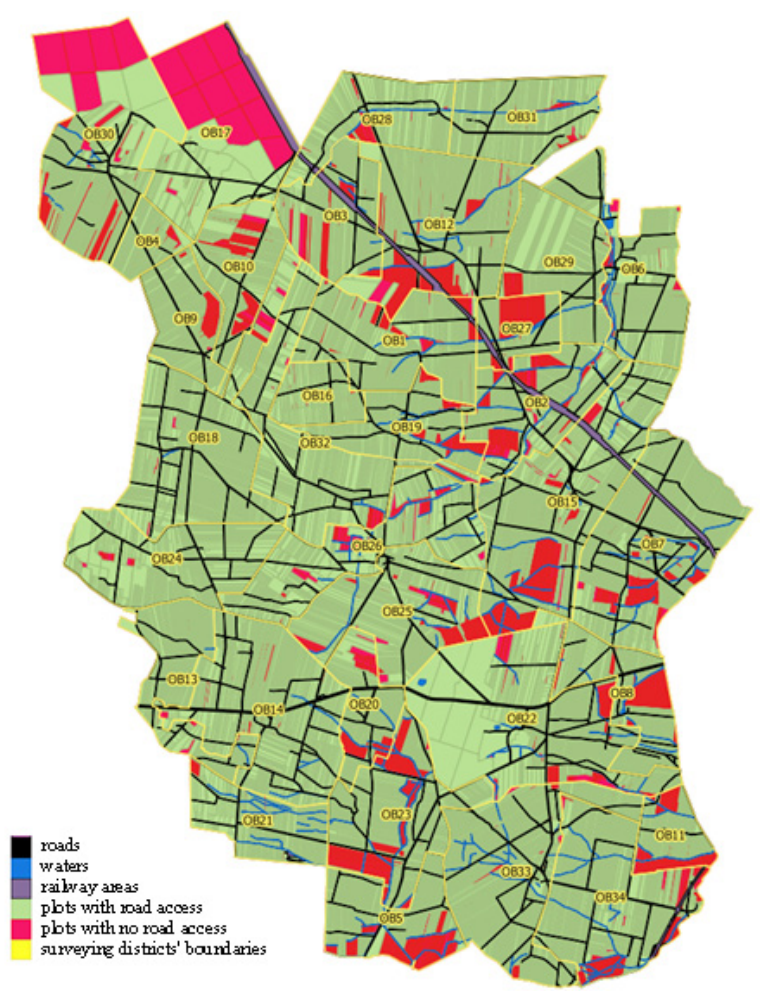

Fig. 1. Spatial image of plots without access to roads in the Sławno unicipality [Głowienka, Leń 2015]

Table 1. The list of factors that describe the desired area accepted for testing

\begin{tabular}{|c|c|c|c|c|}
\hline 1. Possession of land & 2. Use of the land & $\begin{array}{l}\text { 3. Demographic } \\
\text { conditions }\end{array}$ & 4. Fragmentation of land & $\begin{array}{l}\text { 5. Plots with no road } \\
\text { access }\end{array}$ \\
\hline $\begin{array}{l}x_{1}-\% \text { the percentage of } \\
\text { land of individual farms }\end{array}$ & $\begin{array}{c}\mathrm{x}_{5}-\% \text { the percentage of } \\
\text { arable land }\end{array}$ & $\begin{array}{c}\mathrm{x}_{11}-\text { the number of } \\
\text { inhabitants }\end{array}$ & $\mathrm{x}_{13}-$ overall area & $\begin{array}{c}\mathrm{x}_{18}-\% \text { of the number } \\
\text { of plots with no road } \\
\text { access }\end{array}$ \\
\hline $\begin{array}{c}\mathrm{x}_{2}-\% \text { the State Forests } \\
\text { land percentage }\end{array}$ & $\begin{array}{c}\mathrm{x}_{6}-\% \text { the percentage of } \\
\text { medows }\end{array}$ & $\begin{array}{c}\mathrm{x}_{12}-\text { the number of } \\
\text { inhabitants } \\
\text { per } 1 \mathrm{~km}^{2}\end{array}$ & $\begin{array}{c}x_{14}-\text { the total number } \\
\text { of plots }\end{array}$ & $\begin{array}{c}\mathrm{x}_{19}-\% \text { of the plot areas } \\
\text { with no road access }\end{array}$ \\
\hline $\begin{array}{l}\mathrm{x}_{3}-\% \text { the percentage } \\
\text { of the land of the } \\
\text { Agricultural Property } \\
\text { Agency of the Treasury }\end{array}$ & $\begin{array}{c}\mathrm{x}_{7}-\% \text { the percentage of } \\
\text { pastures }\end{array}$ & & $\begin{array}{l}x_{15}-\text { the number of plots } \\
\text { in the individual sector }\end{array}$ & \\
\hline \multirow[t]{3}{*}{$\begin{array}{l}\mathrm{x}_{4}-\% \text { the municipal } \\
\text { land percentage }\end{array}$} & $\begin{array}{c}x_{8}-\% \text { the percentage of } \\
\text { forests }\end{array}$ & & $\begin{array}{l}\mathrm{x}_{16}-\text { the average area } \\
\text { of plots in the individual } \\
\text { sector }\end{array}$ & \\
\hline & $\begin{array}{c}\mathrm{x}_{9}-\% \text { the percentage of } \\
\text { communication areas }\end{array}$ & & $x_{17}-$ fragmentation index & \\
\hline & $\begin{array}{l}\mathrm{x}_{10}-\% \text { the percentage of } \\
\text { building agricultural areas }\end{array}$ & & & \\
\hline
\end{tabular}




\section{METHODS AND RESULTS}

\section{Method for creating rankings}

Method for creating the rankings in the literature is becoming increasingly important. It is applicable in empirical studies of human activity. Such a human activity is the development of agricultural production space shaped by centuries. This development, as concluded in the analyzes presented in the previous section, led in the study area to a very faulty spatial structure of agricultural land. A patchwork land produced in this way requires urgent reconstruction, adapted to the achievements of the XXI century. However, due to the large surface dimensions of this patchwork carrying out the land consolidation and land exchange works for such a large area seems impossible. This applies to personal and financial reasons. Therefore, there is a need to perform analyzes in order to establish a hierarchy of the needs and urgency of the consolidation and exchange of land works, using objective assessment methods. One of such methods is used in the present study, the method of zero unitarisation (MUZ) [Kukuła, 2000].

Comparisons of geometric structures of various villages, distributed in space, require ratings, and then determining rankings for the adopted target of the work. Multi-criteria evaluation must undergo transformation of adopted variables to standardize them. Transformed variables in this method are dimensionless and their sizes have similar values. This method of transformation is called the method of standardization. Standardized values of diagnostic features are subject to aggregation, which allows obtaining a synthetic feature characterizing each village due to the accepted goal. The resulting synthetic values are the basis for the preparation of rankings, arranging the villages in the order from the worst to the best synthetic value. This problem is illustrated in Figure 2.

\section{Determining the priority of villages to carry out the land consolidation and exchange works}

Preliminary analysis covers general characteristics of the distribution of each variable presented in a form of descriptive statistics (Table 2). For each variable it was specified whether it will be treated as a stimulant or destimulant for the ne-

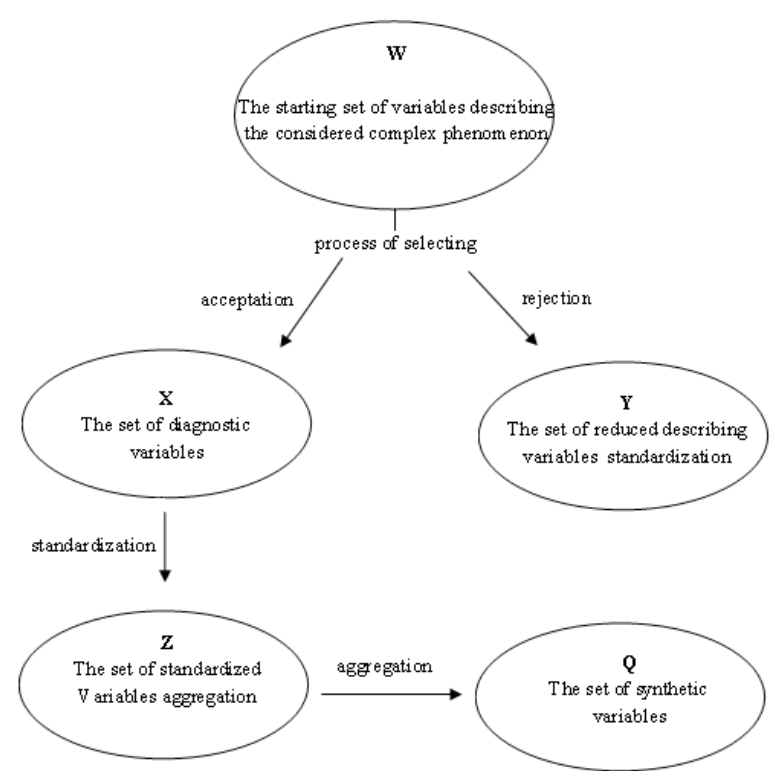

Fig. 2. Scheme of the formation of synthetic variable [Jędrzejczyk et al., 2002]

cessity of the process of land consolidation. 14 features were determined as stimulants, and destimulants included 5 features. It was assumed that higher values of all variables except for the characteristics represented by the indicators: $\mathrm{x}_{2}$, $\mathrm{x}_{3}, \mathrm{x}_{8}, \mathrm{x}_{16}, \mathrm{x}_{17}$, indicate the need for the land consolidation process.

Before preparing the synthetic ranking based on preliminary values of diagnostic features often their pre-selection is carried out. Most common criteria relate to:

- not including variables with low volatility in the analysis (it is often assumed that these are the features for which the coefficient of variation $\mathrm{V}$ is below $20 \%$ );

- the elimination of features highly correlated with each other (because they convey similar information about the hierarchy of the ordered objects).

Criterion of the coefficient of variation is not fulfilled only by the fragmentation rate with $\mathrm{V}=$ $12.3 \%$. But because of substantial value of this variable, it was decided to leave it in the analysis. For the other features, the coefficient of variation exceeds $20 \%$.

Table 3 shows the Spearman correlation coefficient, because the nature of many of dependencies is not necessarily linear. It should be noted that the variables are quite strongly (and some even very strongly) correlated. For example, the average size of plots in the individual sector and 
Table 2. Features selected as stimulants and destimulants of the analyzed features

\begin{tabular}{|c|c|c|c|c|c|c|}
\hline Selected features & Stimulants & & $\mathrm{Me}$ & $\min$ & $\max$ & $V$ \\
\hline$x_{1}-\%$ the percentage of land of individual farms & $\uparrow$ & 80.5 & 89.7 & 1.2 & 98.2 & 27.7 \\
\hline $\mathrm{x}_{4}-\%$ municipal land percentage & $\uparrow$ & 1.6 & 1.5 & 0.0 & 5.7 & 82.5 \\
\hline$x_{5}-\%$ the percentage of arable land & $\uparrow$ & 63.6 & 66.4 & 12.0 & 83.5 & 25.9 \\
\hline$x_{6}-\%$ the percentage of medows & $\uparrow$ & 3.0 & 2.4 & 0.0 & 10.2 & 96.4 \\
\hline $\mathrm{x}_{7}-\%$ the percentage of medows & $\uparrow$ & 7.9 & 6.5 & 1.2 & 19.5 & 62.0 \\
\hline$x_{9}-\%$ the percentage of communication areas & $\uparrow$ & 2.0 & 2.0 & 1.0 & 3.8 & 31.3 \\
\hline$x_{10}-\%$ the percentage of building agricultural areas & $\uparrow$ & 2.4 & 2.3 & 0.2 & 6.0 & 43.5 \\
\hline$x_{11}-$ the number of inhabitants & $\uparrow$ & 227.5 & 208.5 & 25.0 & 667.0 & 60.3 \\
\hline$x_{12}-$ the number of inhabitants per $1 \mathrm{~km}^{2}$ & $\uparrow$ & 62.6 & 59.8 & 4.5 & 133.5 & 42.7 \\
\hline $\mathrm{x}_{13}-$ overall area & $\uparrow$ & 380.8 & 358.2 & 95.0 & 755.3 & 45.7 \\
\hline$x_{14}-$ the total number of plots & $\uparrow$ & 815.7 & 839.5 & 126.0 & 1768.0 & 50.2 \\
\hline $\mathrm{x}_{15}-$ the number of plots in the individual sector & $\uparrow$ & 702.1 & 629.0 & 17.0 & 1726.0 & 58.3 \\
\hline $\mathrm{x}_{18}-\%$ of the number of plots with no road access & $\uparrow$ & 19.9 & 19.0 & 3.9 & 52.0 & 54.9 \\
\hline \multirow[t]{2}{*}{$\mathrm{x}_{19}-\%$ of the plot areas with no road access } & $\uparrow$ & 15.2 & 11.6 & 1.9 & 48.2 & 77.2 \\
\hline & Destimulants & & & & & \\
\hline$x_{2}-\%$ the State Forests land percentage & $\downarrow$ & 7.0 & 0.2 & 0.0 & 74.8 & 226.0 \\
\hline $\begin{array}{l}\mathrm{x}_{3}-\% \% \text { the percentage of the land of the } \\
\text { Agricultural Property Agency of the Treasury }\end{array}$ & $\downarrow$ & 2.7 & 2.0 & 0.6 & 7.2 & 70.6 \\
\hline$x_{8}-\%$ the percentage of forests & $\downarrow$ & 16.8 & 11.1 & 1.2 & 76.9 & 102.6 \\
\hline $\begin{array}{l}x_{16}-\text { the average area of plots in the individual } \\
\text { sector }\end{array}$ & $\downarrow$ & 0.5 & 0.4 & 0.2 & 0.9 & 39.9 \\
\hline $\mathrm{x}_{17}-$ fragmentation index & $\downarrow$ & 3.7 & 3.7 & 2.7 & 4.4 & 12.3 \\
\hline
\end{tabular}

Table 3. The value of the correlation coefficient between selected factor

\begin{tabular}{|c|c|c|c|c|c|c|c|c|c|c|c|c|c|c|c|c|c|c|c|}
\hline & $x_{1}$ & $x_{2}$ & $x_{3}$ & $x_{4}$ & $x_{5}$ & $x_{6}$ & $x_{7}$ & $x_{8}$ & $x_{9}$ & $x_{10}$ & $x_{11}$ & $x_{12}$ & $x_{13}$ & $x_{14}$ & $x_{15}$ & $x_{16}$ & $x_{17}$ & $x_{18}$ & $x_{19}$ \\
\hline$x_{1}$ & 1.00 & & & & & & & & & & & & & & & & & & \\
\hline$x_{2}$ & $-0.65^{*}$ & 1.00 & & & & & & & & & & & & & & & & & \\
\hline$x_{3}$ & -0.33 & 0.18 & 1.00 & & & & & & & & & & & & & & & & \\
\hline$x_{4}$ & -0.23 & 0.36 & -0.09 & 1.00 & & & & & & & & & & & & & & & \\
\hline$x_{5}$ & $0.56^{*}$ & $-0.61^{*}$ & $-0.53^{*}$ & -0.16 & 1.00 & & & & & & & & & & & & & & \\
\hline$x_{6}$ & 0.42 & -0.13 & -0.03 & -0.01 & 0.04 & 1.00 & & & & & & & & & & & & & \\
\hline$x_{7}$ & 0.32 & -0.49 & 0.13 & -0.11 & 0.01 & -0.12 & 1.00 & & & & & & & & & & & & \\
\hline$x_{8}$ & $-0.66^{*}$ & $0.78^{* *}$ & 0.37 & 0.21 & $-0.79^{* *}$ & -0.05 & -0.47 & 1.00 & & & & & & & & & & & \\
\hline$X_{9}$ & 0.09 & -0.11 & -0.10 & 0.03 & 0.24 & -0.11 & 0.13 & -0.25 & 1.00 & & & & & & & & & & \\
\hline$x_{10}$ & 0.34 & $-0.62^{*}$ & -0.06 & 0.02 & 0.31 & 0.25 & 0.48 & $-0.64^{*}$ & 0.26 & 1.00 & & & & & & & & & \\
\hline$x_{11}$ & 0.07 & 0.09 & 0.06 & 0.40 & -0.08 & 0.17 & 0.25 & 0.06 & 0.24 & 0.06 & 1.00 & & & & & & & & \\
\hline$x_{12}$ & 0.25 & -0.41 & 0.28 & 0.10 & 0.04 & 0.07 & 0.49 & -0.25 & -0.10 & 0.43 & 0.48 & 1.00 & & & & & & & \\
\hline$x_{13}$ & -0.21 & 0.46 & 0.04 & 0.31 & -0.25 & 0.02 & -0.19 & 0.37 & 0.25 & -0.28 & $0.64^{*}$ & -0.25 & 1.00 & & & & & & \\
\hline$x_{14}$ & 0.08 & 0.03 & -0.08 & 0.41 & 0.15 & -0.05 & 0.23 & -0.10 & 0.32 & -0.08 & $0.79^{* *}$ & 0.27 & $0.55^{\star}$ & 1.00 & & & & & \\
\hline$x_{15}$ & 0.30 & -0.09 & -0.14 & 0.28 & 0.22 & 0.05 & 0.21 & -0.21 & 0.41 & 0.00 & $0.72^{\star *}$ & 0.17 & $0.58^{*}$ & $0.88^{\star \star}$ & 1.00 & & & & \\
\hline$x_{16}$ & 0.07 & 0.17 & 0.09 & -0.11 & -0.09 & 0.35 & -0.19 & 0.24 & 0.03 & 0.08 & -0.12 & -0.22 & 0.09 & -0.48 & -0.37 & 1.00 & & & \\
\hline$X_{17}$ & 0.12 & 0.22 & 0.10 & $\mid-0.08$ & -0.10 & 0.35 & -0.23 & 0.24 & 0.06 & 0.05 & -0.05 & -0.26 & 0.22 & -0.39 & -0.28 & $0.95^{\star * *}$ & 1.00 & & \\
\hline$X_{18}$ & 0.08 & -0.18 & 0.14 & -0.02 & -0.05 & 0.20 & 0.36 & -0.21 & -0.28 & 0.00 & 0.07 & 0.20 & -0.15 & 0.30 & 0.22 & $-0.63^{*}$ & $-0.56^{*}$ & 1.00 & \\
\hline$x_{19}$ & $\mid-0.12$ & -0.12 & 0.12 & 0.09 & -0.12 & -0.01 & 0.19 & -0.13 & -0.34 & 0.00 & -0.04 & 0.10 & -0.07 & 0.14 & 0.06 & $-0.65^{*}$ & $-0.59^{*}$ & $0.85^{* *}$ & 1.00 \\
\hline
\end{tabular}

Comments: $0.5=<\mathrm{rXY}<0.7$ high correlation*, $0.7=<\mathrm{rXY}<0.9$ very high correlation $* *, 0.9=<\mathrm{rXY}<1$ almost full correlation***. 
fragmentation index $(\mathrm{R}=0.95)$ and the total number of plots and the number of plots in the individual sector $(\mathrm{R}=0.88)$.

Taking into account the substantial importance of the considered variables and their degree of correlation it was decided to include all the variables to creation of the ranking, even though they had a high correlation coefficient.

\section{Determining the priority of villages to carry out the land consolidation and exchange works}

The method of zeroed unitarisation allows normalization of diagnostic variables by examining the range of the feature [Jędrzejczyk, Kukuła, Skrzypek, Walkosz 2002]. Diagnostic variables describing the test object can be divided into three groups [Kukuła 2000]:

1) stimulants - variables whose increasing value increases the assessment of the features of the object, the standardized variables are calculated according to the formula:

$$
Z=\frac{\left(x-x_{\min }\right)}{\left(x_{\max }-x_{\min }\right)}
$$

2) destimulants - variables whose increasing value decreases assessment of the features of the object, the standardized variables are calculated according to the formula:

$$
Z=\frac{\left(x_{\max }-x\right)}{\left(x_{\max }-x_{\min }\right)}
$$

3) nominants - variables which only for a certain value or range of values, take the highest score (optimum); as they move away from the optimum - evaluation of the phenomenon is decreasing, the standardized variables are calculated by:

$$
\begin{aligned}
& Z=\frac{\left(x-x_{\min }\right)}{\left(x_{o p t}-x_{\min }\right)} \text { for } x<x o p t, \\
& Z=\frac{\left(x-x_{\max }\right)}{\left(x_{o p t}-x_{\max }\right)} \text { for } x>x o p t
\end{aligned}
$$

where: $z$-standardized variable,

$x$ - variable before standardization,

$x_{\text {max }}-$ the maximum value of the variable in the given set,

$x_{\min }$ - the minimum value of the variable in the given set,

$x_{\text {opt }}$ - the optimum value of the variable in the given set.

$$
z_{i}=\frac{1}{p} \sum_{j=1}^{p} x_{i j} \quad(\mathrm{i}=1, \ldots, \mathrm{m})
$$

Standardization of diagnostic features is a preliminary stage, allowing to achieve total multi-criteria evaluation of each of the considered objects. The total assessment of each of them can be achieved by aggregation. In order to obtain synthetic measure, mean values are calculated for sets describing the features [Pluta 1986] according to the following formula:

Standardized measures are within the range $<0 ; 1>$. The results can be interpreted as an average value of the optimal values reached by each object. Thus, the object reaches the higher position in the created ranking; the higher value reaches the synthetic measure.

As a result of calculations the obtained level of synthetic meter, allowed a creation of the ranking of the order of the villagesin order to carry on land consolidation and exchange works there. Land consolidation and exchange, in the research area, should be carried out in accordance with the results shown in Table 4.

As it is apparent from the conducted research, in the first place, the works of land consolidation and exchange should be carried out in the villages Kunice (0.64), Gawrony (0.63), Sławno (0.62) which reached the highest value synthetic meter. In another group of villages $(0.60-0.50)$ are: Prymusowa Wola, Grążowice, Janków Psary, Antoniówka, Kozenin, Ostrożna and Kolonia Zachorzów. The research has shown that in the first place works of land consolidation and exchange should be carried out in villages with a high percentage of individual farms land: Kunice (91.1\%), Gawrony (93.5\%), Sławno (89.1\%), a high percentage of the number of plots in the private sector: Kunice (93.6\%), Rooks (97.6\%), Slawno (90.7\%). In selected villages dominates farmland and there is the largest percentage of arable land. The fragmentation of land in these villages is high. The fragmentation index is: Kunice (3.84), Gawrony (3.31), Sławno (3.87). The research has shown that the smallest urgency of the consolidation works is in the Olszewice village, which is characterized by a very high percentage of forest land $(76.9 \%)$, and the percentage of individual farms land is only $1.2 \%$ of the total area of the village. The number of residents in this village is 25 people, which accounts for 4 people at $1 \mathrm{~km}^{2}$. 
Table 4. Ranking of the villages according to the calculated synthetic meter

\begin{tabular}{|c|c|c|c|}
\hline No. & Village & $\begin{array}{c}\text { Synthetic } \\
\text { meter }\end{array}$ & $\begin{array}{l}\text { Position in } \\
\text { the ranking }\end{array}$ \\
\hline 1 & Kunice & 0.64 & 1 \\
\hline 2 & Gawrony & 0.63 & 2 \\
\hline 3 & Sławno & 0.62 & 3 \\
\hline 4 & Prymusowa Wola & 0.56 & 4 \\
\hline 5 & Grążowice & 0.55 & 5 \\
\hline 6 & Janków Psary & 0.53 & 6 \\
\hline 7 & Antoniówka & 0.52 & 7 \\
\hline 8 & Kozenin & 0.52 & 8 \\
\hline 9 & Ostrożna & 0.51 & 9 \\
\hline 10 & Kolonia Zachorzów & 0.51 & 10 \\
\hline 11 & Zachorzów & 0.49 & 11 \\
\hline 12 & Szadkowice & 0.49 & 12 \\
\hline 13 & Owadów & 0.48 & 13 \\
\hline 14 & Antoninów & 0.47 & 14 \\
\hline 15 & Józefów & 0.45 & 15 \\
\hline 16 & Wygnanów & 0.45 & 16 \\
\hline 17 & Kamień & 0.44 & 17 \\
\hline 18 & Dąbrowa & 0.44 & 18 \\
\hline 19 & Olszowiec & 0.43 & 19 \\
\hline 20 & Dąbrówka & 0.41 & 20 \\
\hline 21 & Sławno Kolonia & 0.40 & 21 \\
\hline 22 & Bratków & 0.39 & 22 \\
\hline 23 & Wincentynów & 0.39 & 23 \\
\hline 24 & Kamilówka & 0.38 & 24 \\
\hline 25 & Grudzień Las & 0.37 & 25 \\
\hline 26 & Unewal & 0.37 & 26 \\
\hline 27 & Tomaszówek & 0.37 & 27 \\
\hline 28 & Grudzień Kolonia & 0.36 & 28 \\
\hline 29 & Popławy & 0.36 & 29 \\
\hline 30 & Ludwinów & 0.35 & 30 \\
\hline 31 & Celestynów & 0.33 & 31 \\
\hline 32 & Trojanów & 0.30 & 32 \\
\hline 33 & Sepno Radonia & 0.29 & 33 \\
\hline 34 & Olszewice & 0.13 & 34 \\
\hline
\end{tabular}

\section{CONCLUSIONS}

Łódź Voivodeship is characterized by worse than average in the country's natural conditions for agricultural development, but at the same time, this form of activity is next to industry the main economic specialization of the region. This situation is additionally complicated by the faulty spatial structure of land. The region is dominated by small and very small farms with low pro- ductivity. The rural areas are characterized by insufficient economic and poor social activities, unfavorable situation in terms of equipment in the network devices or restricted access to social services. Therefore, for rural areas and agriculture prevailing there, it is important to restructure agricultural production and improve its quality, aiming at increasing economic efficiency, as well as to improve the civilization conditions of inhabitants. The specificity of farms in Łódź Voivodship and environmental conditions indicate at the possibility of building a strong agricultural sector with eco-agriculture orientation, which will improve the ecological situation of the Voivodship [Development Strategy].

The need of protection of objects of small surface, but valuable in terms of nature, became the reason for the creation of ecological grounds in the area of studied municipality. These areas could not be covered by the reserve protection due to a small area and smaller rank of their natural values than required. In total, in the area of Sławno there are 2.09 ha of ecological grounds, which represent $0.02 \%$ of all land in the municipality and $5.7 \%$ of all ecological grounds in Opoczno District.

Farmland of the study area is characterized by high fragmentation, little surface of plots, often shapeless in form. The road system for the direct service of agricultural land, dating from the period of colonization of the villages in the area, does not provide road access to them from the habitat. While the technical condition of the roads makes it difficult, and sometimes prevents access of agricultural machinery to the plots. Agricultural production in these conditions is burdened with excessive costs, and the development of farms is hindered. Defectiveness occurring in agricultural production space can be eliminated by the implementation of comprehensive works of land consolidation and exchange. This works aim to improve the spatial structure of rural areas. They may also be one of the factors preferably affecting the acceleration of reforms towards transforming the land and building register (EGiB) into a full valuable cadastre in Poland.

Undertaking the works transforming defective land systems across the whole area is not possible due to technical and financial reasons. Therefore, the work of land consolidation and exchange should be taken in these villages, where there are immediate needs. Therefore, it is 
indispensable to assess the degree of defectiveness of the spatial structure of land to determine the need for land consolidation and exchange works, and above all to determine the order of their execution.

\section{REFERENCES}

1. Głowienka E., Leń P. 2016. Zastosowanie metod gis $\mathrm{w}$ analizie struktury przestrzennej obszarów wiejskich gminy sławno w powiecie opoczyńskim. Application of GIS methods in the analysis of the spatial structure of rural areas in Sławno municipality in the Opoczno district. Journal of Civil Engineering, Environment and Architecture. Rzeszow University of Technology. The paper in printing.

2. Jędrzejczyk Z., Kukuła K., Skrzypek J., Walkosz A. 2002. Badania operacyjne $\mathrm{w}$ przykładach $\mathrm{i}$ zadaniach, Operational research in the examples and tasks, Wydawnictwo Naukowe PWN, Scientific Publishers PWN, Warszawa.

3. Kukuła K. 2000. Method of zeroed unitarisation, PWE, Warszawa.
4. Leń P., Głowienka E. 2015. Spatial Analysis of areas without access to a public road in the villages of the municipality Sławno using GIS to tools. Poster XX International Scientific Conference ENVIRO, 18-20 November 2015 Račkova Dolina.

5. Leń P., Wójcik G. 2015. Spatial development of agricultural land division throughout the ages in villages of the Opoczno County. Geomatics And Environmental Engineering Vol. 9/3 2015.

6. Leń P., Noga K. 2010. Analiza rozdrobnienia gruntów indywidualnych we wsiach powiatu Brzozów woj. Podkarpackie, Analysis of individual land fragmentation in the villages of the district Brzozow Podkarpackie Voivodeship [In]: Infrastruktura i Ekologia Terenów Wiejskich, Infrastructure and ecology of rural areas, Polish Academy of Sciences Krakow.

7. Noga K. 2001. Metodyka programowania i realizacji prac scalenia i wymiany gruntów w ujęciu kompleksowym. Methodology of programming and execution of land consolidation and exchange works in the complex attitude. The school of knowledge about the terrain. Kraków.

8. Development Strategy for the Łódź Voivodship for the years 2007-2020.

Pracę dofinansowano ze środków Wojewódzkiego Funduszu Ochrony Środowiska i Gospodarki Wodnej w Lublinie. 